\title{
RESEARCH IN ORGANIZATIONAL CHANGE AND DEVELOPMENT
}




\section{RESEARCH IN ORGANIZATIONAL CHANGE AND DEVELOPMENT}

Series Editors: Abraham B. (Rami) Shani and Debra A. Noumair

Previous Volumes:

Volumes 1-27: Research in Organizational Change and Development 
RESEARCH IN ORGANIZATIONAL CHANGE AND DEVELOPMENT VOLUME 28

\title{
RESEARCH IN ORGANIZATIONAL CHANGE AND DEVELOPMENT
}

EDITED BY

\author{
DEBRA A. NOUMAIR
}

Teachers College, Columbia University, USA

\section{ABRAHAM B. (RAMI) SHANI} California Polytechnic State University, USA

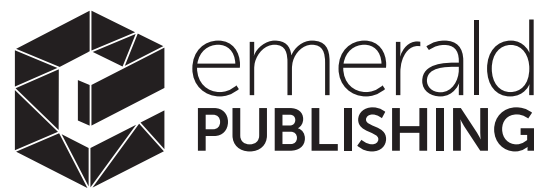

United Kingdom - North America - Japan India - Malaysia - China 
Emerald Publishing Limited

Howard House, Wagon Lane, Bingley BD16 1WA, UK

First edition 2020

Copyright (C) 2020 Emerald Publishing Limited

\section{Reprints and permissions service}

Contact: permissions@emeraldinsight.com

No part of this book may be reproduced, stored in a retrieval system, transmitted in any form or by any means electronic, mechanical, photocopying, recording or otherwise without either the prior written permission of the publisher or a licence permitting restricted copying issued in the UK by The Copyright Licensing Agency and in the USA by The Copyright Clearance Center. Any opinions expressed in the chapters are those of the authors. Whilst Emerald makes every effort to ensure the quality and accuracy of its content, Emerald makes no representation implied or otherwise, as to the chapters' suitability and application and disclaims any warranties, express or implied, to their use.

\section{British Library Cataloging in Publication Data}

A catalog record for this book is available from the British Library

ISBN: 978-1-83909-084-4 (Print)

ISBN: 978-1-83909-083-7 (Online)

ISBN: 978-1-83909-085-1 (Epub)

ISSN: 0897-3016 (Series)

\section{ISOQAR certified}

Management System,

awarded to Emerald

for adherence to

Environmental

standard

ISOQAR

ISO 14001:2004.

REGISTERED

Certificate Number 1985

ISO 14001

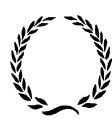

INVESTOR IN PEOPLE 


\section{CONTENTS}

List of Contributors vii

Preface ix

The Social Media Presence of Organization Development: A Social Network Analysis Using Big Data

Donna L. Ogle, Ramkrishnan (Ram) V. Tenkasi and William (Bart) B. Brock

Constructing the Professional Identity of the Renowned American Women of Organizational Change: A Story of Their Lives

David B. Szabla, Elizabeth Shaffer, Ashlie Mouw and Addelyne Turks

Community in the New World of Work: Implications for Organizational Development and Thriving Gretchen Spreitzer, Peter Bacevice, Hilary Hendricks and Lyndon Garrett

Digitalization in Schools: Four Examples of Embeddedness Johan Klaassen and Jan Löwstedt

Organizational Resilience: Antecedents, Consequences, and Practical Implications - for Managers and Change Leaders Orit Shani

Management Is Missing in Change Management

Laurie W. Ford and Jeffrey D. Ford

Change in Tightly Coupled Systems: The Role and Actions of Middle Managers

Rita Berggren, Johanna E. Pregmark, Tobias Fredberg and Björn Frössevi 
Why Honest Conversations are Transformative

Michael Beer

About the Contributors 


\section{LIST OF CONTRIBUTORS}

Pete Bacevice

Michael Beer

Rita Berggren

William (Bart) B. Brock

Jeffrey D. Ford

Laurie W. Ford

Tobias Fredberg

Björn Frössevi

Lyndon Garrett

Hilary Hendricks

Johan Klaassen

Jan Löwstedt

Ashlie Mouw

Donna L. Ogle

Johanna E. Pregmark

Elizabeth Shaffer

Orit Shani

Gretchen Spreitzer
HLW and Ross School of Business, University of Michigan, USA

Harvard Business School, TruePoint Partners, and Center for Higher Ambition Leadership, USA

Technology Management and Economics, Chalmers University of Technology, Sweden

Colorado Christian University, USA

The Ohio State University, USA

United States Nuclear Industry Council, USA

Technology Management and Economics,

Chalmers University of Technology, and

Center for Higher Ambition Leadership Europe,

Sweden

Partner, TruePoint Europe, Sweden

Carroll School of Management, Boston College, USA

Ross School of Business, University of Michigan, USA

Stockholm Business School, Stockholm University, Sweden

Stockholm Business School, Stockholm University, Sweden

Western Michigan University, USA

Rockford University, USA

Technology Management and Economics,

Chalmers University of Technology, and

Center for Higher Ambition Leadership Europe, Sweden

Western Michigan University, USA

Organizational and Resilience Consulting, Israel

Ross School of Business, University of Michigan, USA 
David B. Szabla

Ramkrishnan (Ram)

V. Tenkasi

Addelyne Turks
Western Michigan University, USA

Daniel L. Goodwin College of Business, Benedictine University, USA

Western Michigan University, USA 


\section{PREFACE}

This volume of Research in Organization Change and Development continues the long-established tradition of providing a special platform for scholars, practitioners, and scholar-practitioners to share new thoughts provoking researchbased insights. JAI Press published the first annual volume of Research in Organization Change and Development in 1987. Since 2009 and for the last 12 volumes, our partner in publishing ROCD, Emerald, has enhanced the quality of this special publication for scholars and practitioners.

Volume 28 of Research in Organizational Change and Development continues the practice of providing insightful chapters. Coupling the most recent period of COVID-19 and its impact on individuals, organizations, networks, and societies with the initial AOM major conference theme provided, "20/20: Broadening our Sights", framed a wide terrain within which to explore organization development and change. Although not addressed directly, the invitation to use the theme, 20/20 Vision, to see more clearly management and organizations is apparent in the chapters in this volume. All contributions provide relevant insights which support broadening our sights for influencing our understanding of organization change and development.

Taking a 20/20 perspective while utilizing big data and social network analysis magnified the current state of the organization development field. The careful examination of renowned American women in the field explores the role of professional identity. The emerging nature of the new world of work suggests a fresh examination of the essence and role of communities that support interpersonal learning and enhance workers ability to thrive. The presence of technology and technological embeddedness is investigated as a change and development enabler. The variability of organizational resilience suggests an arena for organization development work that can broaden the impact of the field. The view of systems as networks of agreements and transfer of products, services, and communication provides a way to restore management in organization development and change management. Examination of change in tightly coupled systems magnifies the middle management role in organization development efforts. Last, while honest conversations have long been at the core of organization development and change work, strategic fitness processes present an approach that can broaden the ability to improve organization effectiveness and performance.

These contributions represent a commitment to the future. Many times over the years, we have been asked the question "Is there still a vibrant scholarly community in organization development?". The answer is a resounding yes, as 
those of you who have attended professional conferences like the Academy of Management, Organization Design Forum, or Organization Development Network will attest. While the field continues to evolve, the need for organizational change has never been more apparent than it is today, amid corruption, economic inequities, discrimination, continuing wars, and threats to the sustainability of the planet. It is no surprise to us that scholars in our field are stepping up to help address these challenges.

The field continues to evolve and increase our understanding of the complexities of organizational development and change. While we are smarter about it now than 70 years ago when the field began, we are still far from mastery or efficiency. We have models and principles to follow and a great deal of research to support what does and does not work. Yet, we are lacking a surefire formula for success, and it is our belief that due to the inherently human and emotional nature of change in organizational settings that no such formula will ever be found. That said we are improving the start of the art, as the papers in this volume attest. Some of these papers bring new perspectives to classic issues in the field such as actually including management in change management. Others explore new territories, such as the role of "technological embeddedness" as mechanisms to create more inclusive and sustainable change. From our editorial perspective, one of the most wonderful things about our work on this series is that it always brings surprises, whether in the form of a new way of thinking about old problems or a different way to think about opportunities we did not know existed. The series has been around long enough to substantiate the claim that we have published some true classics in the field of organization development and change. While it is too early to say whether the papers in Volume 28 contain new classics, there are certainly some significant and worthwhile pieces to read, which have the potential to become classics at some time in the future.

Leading off, Volume 28 is a paper by Donna Ogle, Ram Tenkasi, and Bill Brock that provides a comprehensive analysis of the field through the eyes of social media by using big data based on 5.7 million tweets extracted through Twitter's API. Using social network analysis, the authors provide a comparative perspective on the state of organization development in relations to other management and organization studies fields. The authors advocate for greater specialization of organization development. David Szabla, Elizabeth Shaffer, Ashlie Mouw, and Addelyne Turks, building on the profiles of 17 of the women included in The Palgrave Handbook of Organizational Change Thinkers, perform a narrative analysis based upon the concepts and models prevalent in the literature on identity formation. By focusing on the professional identity formation of these women in the field, the authors suggest effective ways to prepare individuals to work in and advance the field.

Gretchen Spreitzer, Pete Bacevice, Hilary Hendricks, and Lyndon Garrett, while focusing on the emerging "coworking space," pair recent research on human thriving with trends they observe in organizations' efforts to create and maintain a sense of community. Such communities, they argue, provide 
opportunities for interpersonal learning and vitality that can enhance thriving. Johan Klaassen and Jan Löwstedt examine the introduction processes of two separate IT systems in a school organization and their impact. The authors introduce the concept of "illusive embeddedness" and suggest a model of change processes that can enhance different levels of technological embeddedness in schools. Orit Shani conducted a comprehensive study of 1,132 educators in 98 schools, which explored the essence of organizational resilience. The author discovered significant relationships between three antecedents (social capital, team empowerment, goal interdependence) and organizational resilience; a positive significant relationship between organizational resilience and organizational functioning in crisis; and organizational resilience as a mediator between three of the antecedents (social capital, team empowerment, goal interdependence) and organizational functioning in crisis. Implications for policy makers, managers, and change leaders are explored.

Laurie Ford and Jeffrey Ford, the recipients of last year's Pasmore and Woodman Award, reflecting on 30 years of collaboration, broaden our sight by sharing an operations research-based approach to representing systems as networks of agreements and transfers of products, services, and communications that they practice. They distinguish the network approach that is foundational to their work, with its implications for organization change and the "missing" elements of management. They conclude with reflections on restoring management to change management. Rita Berggren, Johanna Envall Pregmark, Tobias Fredberg, and Björn Frössevi investigated three retail organizations characterized as tightly coupled systems and examine the challenges that they faced in becoming adaptive and agile organizations. They identified three critical and central realignment mechanisms. The role of middle managers as facilitator of such mechanisms is explored. Last, Michael Beer, reflecting on the past 30 years of work, magnifies the role of honest conversation in individual and system transformation. Illustrating the Strategic Fitness Processes, the author argues that by creating a container for honest, collective, and public conversations, it enables leaders not naturally inclined or skilled in leading these conversations to learn how and potentially change their values and capabilities to do so.

From our editorial perspective, one of the best parts of our work on this series is that our collaborations with the authors always brings new learning, whether in the form of making history accessible and relevant, challenging assumptions, extending theory in creative ways, or integrating perspectives that heretofore have remained separate. The series has been around long enough to substantiate the claim that we have published some true classics in the field of organization change and development. We have also provided scholarpractitioners across career stage, sector, and geography with a platform to share their work and for colleagues to learn from each other in order to inform future collaborations. Moreover, the ROCD series has provided reliable sources for contributing to the ongoing development of organization change and development theory, research, and practice. It is our hope that through the 
volume, you will consider your own thoughts and practice and possible contributions to the field as we are all dealing with COVID-19 and its impact, and contact us to suggest topics or themes for future volumes.

Debra A. Noumair Abraham B. (Rami) Shani

Editors 